\title{
INCREASING LONGEVITY AND SOCIAL SECURITY REFORMS
}

\author{
TORBEN M. ANDERSEN
}

CESIFO WORKING PAPER NO. 1789

CATEGORY 1: PubliC Finance

August 2006

An electronic version of the paper may be downloaded

- from the SSRN website:

- from the RePEc website:

- from the CESifo website:

http://www.SSRN.com/abstract $=932493$

www.RePEc.org

www.CESifo-group.de 


\title{
INCREASING LONGEVITY AND SOCIAL SECURITY REFORMS
}

\begin{abstract}
Increasing longevity causes an upward trend in the dependency ratio in many countries. This raises concerns about the financial sustainability of social security schemes, and reform initiatives and proposals abound. It is shown that a fundamental policy choice inevitably arises since a given social security system cannot be maintained by simply indexing retirement ages and benefits to longevity. The political reform process is analysed using the so-called legislative procedure. When longevity increases, the young generation contributes more, and the old generation faces lower benefits and a retirement age that increases more than proportionally to the increase in longevity.
\end{abstract}

JEL Code: D72, H55, J11, J14, J18.

Keywords: longevity, social security, political economy.

Torben M. Andersen

School of Economics and Management

University of Aarhus

8000 Aarhus C

Denmark

tandersen@econ.au.dk

August 2006

Comments and suggestions by the discussant Y. Algan and participants at the workshop The Political Economy of Welfare State Reforms, Paris are gratefully acknowledged. 


\section{Introduction}

Social security systems are in focus due to undergoing demographic shifts, in particular as a result of increasing longevity. According to UN forecasts (UN (2004)), life expectancy in Western European countries is expected to rise on average 0.2 years per year over the next 50 years. Most countries face the challenge of how to exploit the opportunities arising from increasing longevity and the implied increase in the share of old people in populations (see e.g. EU (2006) and IMF (2004)).

Most countries have social security systems that do not include automatic responses to changes in longevity. Therefore, political decisions are needed to ensure the viability of the systems. Often, social security systems have given statutory pension (and retirement) ages, and these age limits have remained invariant (or have even in some cases declined) despite increases in longevity, cf. figure 1. Moreover, most social security systems are of the defined benefit type providing a given benefit (could depend on past earning and be indexed) from the statutory pension age and until death, see e.g. Werding (2004), that is, a life annuity is provided. It follows straightforwardly that the combination of given statutory pension ages and benefits provided as life annuities lead to financial problems if longevity increases.

Figure 1: Life expectancy and age of retirement
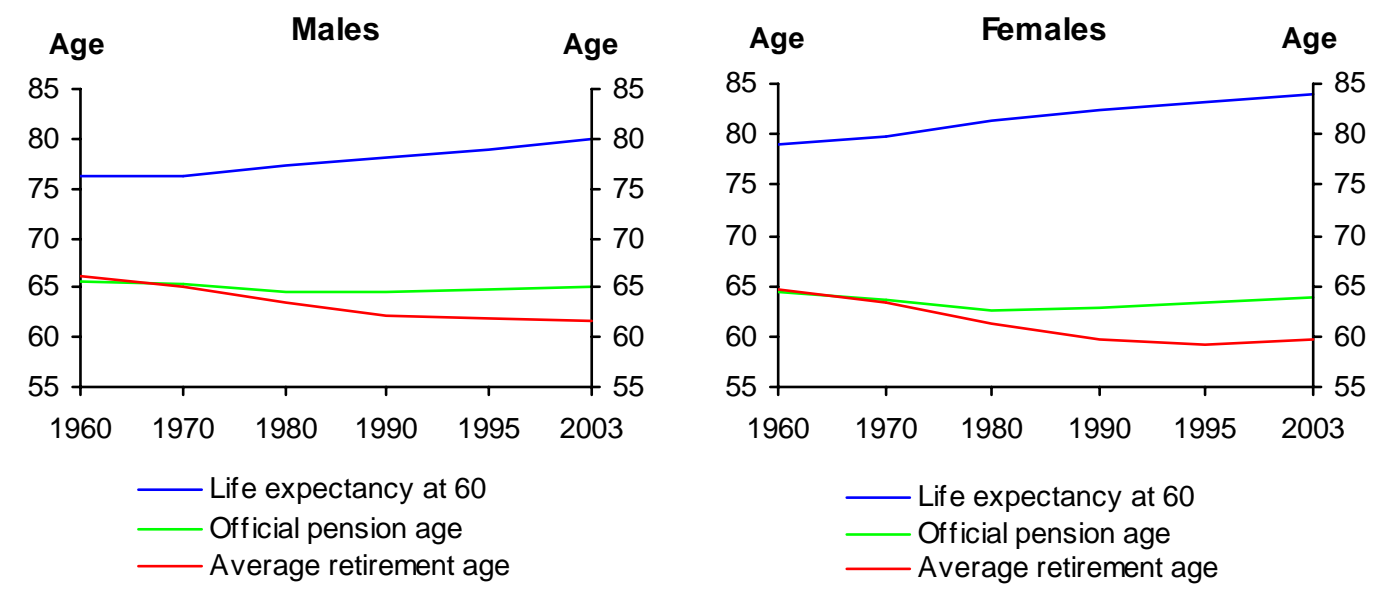

Note: Average for 20 OECD countries.

Source: Velfærdskommissionen (2005).

A highly topical policy issue is concerned with how to adapt the social security scheme to changes in the demographic composition and in particular to the increase in longevity. This issue is debated widely in most countries, and some countries have already undertaken some reforms. Recent reforms or reform proposals in e.g. US, UK, Germany etc. implies that both pension ages 
and contribution rates are going to increase. One interesting aspect is that some recent reforms have explicitly made the properties of the social security system contingent on longevity, either by adjusting benefits to longevity ${ }^{1}$ or by making eligibility ages dependent on longevity. Examples of the former ${ }^{23}$ are found in e.g. Sweden, Italy, Poland and Latvia, and the latter in Denmark.

There is a voluminous literature on social security schemes, but, surprisingly, the issue of longevity has not attracted much attention (see however Auerbach and Hassett(2004a,b) and Andersen (2005)). The debate has mainly centred on the implications of an increase in the dependency ratio driven by more old relative to young (change in fertility). While this is also an implication of increases in longevity, it is important to be explicit about the reason for the increase in the dependency ratio ${ }^{4}$. When the dependency ratio increases due to longer longevity, it is an implication that the marginal utility of a given present value of benefits increases (the money has to be spent over a longer period) and disutility of work decreases (ceteris paribus the retirement period becomes longer), see Andersen (2005). Hence, the question of how to adjust the properties of the social security scheme - contribution rates, benefits and retirement age - to changes in longevity is not trivial (see also Mulligan and Xala-I-Martin(2003,2004a)).

The political economy literature on social security systems has mainly focused on the fact that demographic changes may have a direct influence on the political balance by changing the relation between old and young voters, see Galasso and Profeta (2002) and Mulligan and Xala-I-Martin (2004b) for surveys. The larger part of the literature has addressed one-dimensional social security systems with a transfer from young to old. However, most social security systems stipulate transfers as a life annuity from a given statutory pension/retirement age (see Werding (2004), and Mulligan and Xala-I-Martin $(2004 b))$. It is therefore important to allow for policy reforms changing both the benefit rates and retirement ages for the old alongside contributions made by the young. Another branch of the literature has focused on early retirement schemes (see e.g. Conde-Ruiz and Galasso $(2003,2004)$ and Cremer, Lozachmeur and Pestieau (2006)), which is an important issue in many countries. Early re-

\footnotetext{
${ }^{1}$ In an actuarial system, the benefit level would of course adjust to the period over which the funds are to be distributed.

${ }^{2}$ Note that Germany has introduced a sustainability factor where benefit levels are made dependent on the dependency ratio.

${ }^{3}$ This is in the form of a so-called notional defined contribution scheme, see e.g. BörschSupan (2004). This scheme is characterized by pension rights being accumulated in a notional way based on individual contributions, but the actual pension benefits are determined on a PAYG basis but proportional to individual rights. In calculating the benefit, there can be some adjustment for e.g. longevity as in e.g. the Swedish case.

${ }^{4}$ The other main reason for an increase in the dependency ratio is the trend decline in fertility, i.e. high fertility in the 1940 s and 1950 s and lower fertility in subsequent periods. Adaptation of the social security system to the change in fertility is a backward looking problem, since the changes in fertility cannot be undone. The changes caused by longevity are forward-looking in the sense that this relates to an ongoing process. Note that an increase in fertility would not directly remedy the consequences of increasing longevity. The reason is that new-borns also will have a long life-expectancy.
} 
tirement schemes relate to heterogeneity across people in respect to earnings ability, health etc. In the present paper, attention is focused on longevity and therefore all agents are assumed identical. However, longevity may be related to various socio-economic variables ${ }^{5}$ and therefore an important question for future research is how this affects the need for early retirement schemes.

The purpose of this paper is to consider the implications of changes in longevity in a social security system of the pay-as-you-go type. The main interest here is to consider how the system would be adjusted in terms of the three dimensions - contributions, benefits and retirement ages. In addressing this question, a simple OLG model allowing for both changes in longevity and differences in longevity across generations is used.

The approach taken here is to view the social security system as the outcome of a legislative procedure among all living generations (see Hansson and Stuart (1989)). That is, all living generations at a given point in time have an influence on the properties of the social security system, and future generations may change the system according to their preferences. It is assumed that a unanimity requirement applies ${ }^{6}$. The reason for adopting this approach is first that it captures the fact that all living agents (old and young) can have a common interest in adopting a social security system of a PAYG nature (see Hansson and Stuart (1989)), even under a decision procedure providing the young with a veto power ${ }^{7}$. Moreover, in the present context, the results are not simply driven by increased longevity changing the political balance between young and old voters gradually over time (with increasing longevity the share of old to young individuals will rise over time). The results are thus not driven by old generations becoming a more powerful group (see IMF(2004)). Finally, the approach taken here has the advantage that it considers social security schemes which can be implemented, rather than focussing on the social optimal scheme. As shown, it is, however, possible to interpret the utilitarian social optimum as a special case of the framework used.

This paper is organised as follows: Section 2 develops the OLG model used in the analysis, and section 3 shows how the properties of the social security system are decided under the legislative approach. Section 4 explores how the properties of the social security system - contributions, benefits and retirement age - depend on the longevity of different generations. Section 5 concludes and offers some policy conclusions.

\footnotetext{
${ }^{5}$ Empirical evidence shows that there are such differences, but also that the increase in longevity is more or less proportional across groups, except for groups with severe health problems, cf Velfærdskommissionen (2006).

${ }^{6}$ Azariadis and Galasso (2002) show that a constitutional rule granting veto power to minorities is equivalent to a precommitment. Therefore, it eliminates indeterminacies and inefficiencies.

${ }^{7}$ The mechanism sustaining the scheme is that each generation saves less to force later generations with some altruism to make transfers to the older generations.
} 


\section{Overlapping generations model - variable life time and endogenous retirement ${ }^{8}$}

Consider an economy with access to an international capital market offering a risk-free asset with return $r$, which for simplicity is assumed constant throughout time.

Agents live through two life phases, one denoted young and the other old. Fertility and thus the number of new borns is constant, but longevity may change. The first phase has a given length normalized to unity, while the second has length $\beta(\leq 1)$. A change in longevity is thus a change in $\beta$.

Denote the generation being young in period $t$ as generation $t$. In youth they work and enjoy consumption $c_{1 t}$, yielding utility ${ }^{9}$

$$
u\left(c_{1 t}\right) \quad u^{\prime}>0, u^{\prime \prime} \leq 0
$$

Disutility of work during youth is constant and therefore disregarded to simplify the exposition.

In the second period of life, agents of generation $t$ are alive for a period of length $\beta_{t+1}$ (the total length of the period being normalized to one, $\beta_{t+1} \leq 1$ ), and they work a fraction of this period $\alpha_{t+1}\left(\leq \beta_{t+1}\right)$. The retirement period is thus $\beta_{t+1}-\alpha_{t+1}$. To simplify, it is assumed that life length is deterministic ${ }^{10}$. The marginal product of labour is constant and the same for young and old workers, and for simplicity normalized to unity. The labour market is assumed competitive, and the real wage is normalized to equal one.

Total consumption as old is $c_{2 t+1}$ yielding a consumption stream of $\frac{c_{2 t+1}}{\beta_{t}}$, implying that the utility from consumption in the old phase of life is (see Auerbach and Hassett $(2002 \mathrm{a}, \mathrm{b}))$

$$
\beta_{t} u\left(\frac{c_{2 t+1}}{\beta_{t}}\right)
$$

Note that this specification implies that agents value long life time ceteris paribus, but the utility function implies a trade-off between longevity and consumption. ${ }^{11}$

Disutility of work as old is given as

$$
\alpha_{t} v\left(\frac{\alpha_{t}}{\beta_{t}}\right) ; v^{\prime}>0, v^{\prime \prime}>0, \lim _{\alpha \longrightarrow \beta} v^{\prime}=\infty
$$

Hence, the usual convexity of the disutility of work is assumed, and the last condition ensures that there always is some "retirement" period $(\alpha<\beta)$. For

\footnotetext{
${ }^{8}$ This section builds on Andersen (2005).

${ }^{9}$ Note that the utility function is assumed to be the same across generations.

${ }^{10}$ Individual uncertainty around a given generational mean can easily be incorporated by also allowing an annuities market, see e.g. Yaari (1965).

${ }^{11}$ It could be argued that preferences are lexicographic, i.e. longevity is evaluated above material consumption flows.
} 
later reference it is useful to define the marginal disutility of work (retirement) as old by

$$
\eta\left(\frac{\alpha_{t}}{\beta_{t}}\right) \equiv \frac{\partial}{\partial \alpha}\left(\alpha_{t} v\left(\frac{\alpha_{t}}{\beta_{t}}\right)\right)=v\left(\frac{\alpha_{t}}{\beta_{t}}\right)+\frac{\alpha_{t}}{\beta_{t}} v^{\prime}\left(\frac{\alpha_{t}}{\beta_{t}}\right)
$$

where $\eta^{\prime}=2 v^{\prime}+\frac{\alpha}{\beta} v^{\prime \prime}>0, n^{\prime \prime}=3 v^{\prime \prime}+\frac{\alpha}{\beta} v^{\prime \prime \prime} \gtreqless 0$. Note that for $\frac{\alpha}{\beta}$ sufficiently large it follows that (given that $\lim _{\alpha \longrightarrow \beta} v^{\prime}=\infty$ ) $v^{\prime \prime \prime}>0$.

Direct utility to the generation being young in period $t$ is thus

$$
V_{t}\left(c_{1 t}, c_{2 t+1}, \alpha_{t+1}, \beta_{t+1}\right)=u\left(c_{1 t}\right)+\frac{1}{1+\theta}\left[\beta_{t+1} u\left(\frac{c_{2 t+1}}{\beta_{t+1}}\right)-\alpha_{t+1} v\left(\frac{\alpha_{t+1}}{\beta_{t+1}}\right)\right]
$$

where $\theta$ is the subjective discount rate. Note that $V_{c_{1}}^{\prime}>0, V_{c_{2}}^{\prime}>0, V_{\alpha}^{\prime}<0$, and $V_{\beta}^{\prime} \lesseqgtr 0$.

Assume that each generation has a concern - altruism - with respect to other generations such that the objective or political preference function for the period $t$ young reads

$$
\begin{gathered}
W_{t}=V_{t-1}\left(c_{1 t-1}, c_{2 t}, \alpha_{t}, \beta_{t}\right) \frac{1}{(1+\rho)}+V_{t}\left(c_{1 t}, c_{2 t+1}, \alpha_{t+1}, \beta_{t+1}\right) \\
+\sum_{i=1}^{\infty}[1 /(1+\delta)]^{i} V_{t}\left(c_{1 t+i}, c_{2 t+i+1}, \alpha_{t+i+1}, \beta_{t+i+1}\right)
\end{gathered}
$$

where the utility of current old is discounted by the rate $\rho$, and the utility of future generations is discounted by $\delta$, which may possibly differ from $\rho$. That is, the first term in (2) is the influence the utility of the current old has on the young, the second term is the direct utility to the young generation, and the final term captures the influence of the utility to future generations. Note also that the utilitarian case arises as the special case where both $\rho$ and $\delta$ are equal to zero. Alternatively, the parameters $\rho$ and $\delta$ can be interpreted as capturing a political bias away from the utilitarian case. The higher $\rho$, the less the concern for the current old, and the higher $\delta$, the less the concern for future generations. Hence, $\rho$ and $\delta$ can be interpreted as a measure of the degree of egoism or altruism - if equal to zero we have the altruistic case, if equal to infinity we have the egoistic case.

Inserting the utility function (1) in (2), we get that the political preference function for the generation being young in $t$ reads

$$
\begin{gathered}
W_{t}=\left[u\left(c_{1 t-1}\right)+\frac{1}{1+\theta} E_{t}\left[\beta_{t} u\left(\frac{c_{2 t}}{\beta_{t}}\right)-\alpha_{t} v\left(\frac{\alpha_{t}}{\beta_{t}}\right)\right]\right] \frac{1}{(1+\rho)} \\
+\left[u\left(c_{1 t}\right)+\frac{1}{1+\theta} E_{t}\left[\beta_{t+1} u\left(\frac{c_{2 t+1}}{\beta_{t+1}}\right)-\alpha_{t+1} v\left(\frac{\alpha_{t+1}}{\beta_{t+1}}\right)\right]\right] \\
+\sum_{i=1}^{\infty}[1 /(1+\delta)]^{i}\left[u\left(c_{1 t+i}\right)+\frac{1}{1+\theta} E_{t}\left[\beta_{t+i+1} u\left(\frac{c_{2 t+i+1}}{\beta_{t+i+1}}\right)-\alpha_{t+i+1} v\left(\frac{\alpha_{t+i+1}}{\beta_{t+i+1}}\right)\right]\right]
\end{gathered}
$$




\section{No social security}

For later reference it is useful to consider the special case where there is no social security scheme and thus no mechanism for intergenerational transfers (bequests are ruled out). Alternatively, this may be interpreted as the limiting case with egoistic young generations $(\delta=\rho \rightarrow \infty)$. It is straightforward to show that the individual's decision making implies the following first order conditions

$$
\begin{aligned}
u^{\prime}\left(c_{1 t}\right) & =\frac{1+r}{1+\theta} u^{\prime}\left(\frac{c_{2 t+1}}{\beta_{t+1}}\right) \\
u^{\prime}\left(\frac{c_{2 t+1}}{\beta_{t+1}}\right) & =\eta\left(\frac{\alpha_{t+1}}{\beta_{t+1}}\right)
\end{aligned}
$$

where (4) determines the allocation of consumption between the life phases of young and old, and (5) determines the retirement as old.

\section{Social security}

Consider next the presence of a social security scheme of a PAYG type. It is assumed that the introduction and properties of such a scheme are decided in a political process according to the legislative approach proposed by Hansson and Stuart (1989). This implies that all living generations have an influence on the social security scheme, and they all have a veto power. While this may seem a restrictive way of modelling the political process, it has the advantage of identifying schemes which can always be implemented.

Specifically, we consider the choice of the properties of a social security scheme belonging to the following family where the old in period $t+1$ receives a transfer

$$
\tau_{t+1}\left(\beta_{t+1}-\alpha_{t+1}\right)
$$

The transfer is proportional with the factor $\tau_{t+1}$ to the retirement period $\left(\beta_{t+1}-\alpha_{t+1}\right)$ where $\alpha_{t+1}$ is the retirement age stipulated in the social security scheme. Note that the interpretation is that the transfer is paid from retirement at age $\alpha_{t+1}$ for the remaining life time (life annuity). The parameters of the scheme are thus the benefit ratio $\tau$ and the retirement age $\alpha$. The transfer to the old is financed in a lump sum fashion by the young.

The reason for considering this particular social security scheme is twofold. First, it replicates, to a first order approximation, the social security scheme in many countries. Second, it is very difficult to solve in general for the optimal structure of the social security scheme.

Under the social security scheme the budget constraints of young reads

$$
c_{1 t}+s_{t}=1-T_{t}
$$

where $s$ denotes savings, and $T$ the lump sum tax. Consumption as old in period $t+1$ is

$$
c_{2 t+1}=\alpha_{t+1}+(1+r) s_{t}+\tau_{t+1}\left(\beta_{t+1}-\alpha_{t+1}\right)
$$


Note that the benefit ratio becomes an implicit tax on the retirement decision since

$$
\frac{\partial c_{2 t+1}}{\partial \alpha_{t+1}}=1-\tau_{t+1}<1
$$

The budget constraint for the social security scheme (PAYG) reads

$$
T_{t}=\tau_{t}\left(\beta_{t}-\alpha_{t}\right)
$$

The solution procedure is to consider the decision taken by young and old generations alive at a given period in time on the properties of the social security scheme and savings, i.e. $(\tau, \alpha, s)$. Decisions made by previous generations are taken as given. In the same way, later generations will decide on the social security scheme. The objective is to find a scheme which future generations will not amend. The approach taken ensures that the choice of $(\tau, \alpha, s)$ for the introducing generation is a sub-game perfect equilibrium, i.e. sustained by subsequent generations.

\section{Designing social security}

The procedure is first to consider the optimal design of the social security system from the point of view of generation $t-1$, i.e. the old generation in period $t$ (see Hansson and Stuart (1989)). The optimal choice of $\left(\tau_{t}, \alpha_{t}\right)$ is determined by the first order conditions (note that savings are predetermined as young)

$$
\begin{aligned}
u^{\prime}\left(\frac{c_{2 t}}{\beta_{t}}\right)\left(\beta_{t}-\alpha_{t}\right) & =u^{\prime}\left(c_{1 t}\right) \frac{1}{(1+\delta)}\left(\beta_{t}-\alpha_{t}\right) \\
\eta\left(\frac{\alpha_{t}}{\beta_{t}}\right) & =\left(1-\tau_{t}\right) u^{\prime}\left(\frac{c_{2 t}}{\beta_{t}}\right)+\frac{1}{(1+\delta)} \tau_{t} u^{\prime}\left(c_{1 t}\right)=u^{\prime}\left(\frac{c_{2 t}}{\beta_{t}}\right)
\end{aligned}
$$

and the choice of $\left(\tau_{t+j}, \alpha_{t+j}, s_{t+j-1}\right)$ for any $j>0$ is determined by

$$
\begin{gathered}
u^{\prime}\left(\frac{c_{2 t+j}}{\beta_{t+j}}\right)\left(\beta_{t+j}-\alpha_{t+j}\right)=u^{\prime}\left(c_{1 t+j}\right) \frac{1}{(1+\delta)}\left(\beta_{t+j}-\alpha_{t+j}\right) \\
\eta\left(\frac{\alpha_{t+j}}{\beta_{t+j}}\right)=\left(1-\tau_{t+j}\right) u^{\prime}\left(\frac{c_{2 t+j}}{\beta_{t+j}}\right)+\frac{1}{(1+\delta)} \tau_{t+j} u^{\prime}\left(c_{1 t+j}\right)=u^{\prime}\left(\frac{c_{2 t+j}}{\beta_{t+j}}\right) \\
u^{\prime}\left(c_{1 t+j-1}\right) \geq \frac{1+r}{1+\theta} u^{\prime}\left(\frac{c_{2 t+j}}{\beta_{t+j}}\right) \text { and } s_{t+j-1}\left(u^{\prime}\left(c_{1 t+j-1}\right)-\frac{1+r}{1+\theta} u^{\prime}\left(\frac{c_{2 t+j}}{\beta_{t+j}}\right)\right)=0
\end{gathered}
$$

For generation $t$ the optimal choice of $\left(\tau_{t}, \alpha_{t}\right)$ is determined by the foc

$$
\begin{gathered}
u^{\prime}\left(\frac{c_{2 t}}{\beta_{t}}\right)\left(\beta_{t}-\alpha_{t}\right) \frac{1}{1+\rho}=u^{\prime}\left(c_{1 t}\right)\left(\beta_{t}-\alpha_{t}\right) \\
\eta\left(\frac{\alpha_{t}}{\beta_{t}}\right) \frac{1}{1+\rho}=\left(1-\tau_{t}\right) u^{\prime}\left(\frac{c_{2 t}}{\beta_{t}}\right) \frac{1}{1+\rho}+\tau_{t} u^{\prime}\left(c_{1 t}\right)=u^{\prime}\left(\frac{c_{2 t}}{\beta_{t}}\right) \frac{1}{1+\rho}
\end{gathered}
$$


while (12),(13) and (14) apply for all $j>0$.

Note that when $\left(\tau_{t}, \alpha_{t}\right)$ are fixed, generation $t-1$ and $t$ will find the same sequence of $\left(\tau_{t+j}, \alpha_{t+j}, s_{t+j-1}\right)$ to be optimal $(j>0)$. The properties of the social security scheme will be taken as exogenous to the individual, implying that condition (14) holds. No future generations will be able to amend the law. The reason is simple; the conditions for optimality for the old generation are precisely (12),(13), and the old generation can therefore block any proposed legislative change, which means that the law is never amended (Hansson and Stuart (1989)).

The key to the existence of social security is thus that the founding generations are better off than in the case of no social security system and that there is no scope for any further Pareto improving transfers between the founding generations. For a demonstration that an equilibrium with social security exists, see Hansson and Stuart (1989).

The distributional conflict between the founding old and young generation is easily seen by noting that (10) and (15) present the view of the current old on the distribution between old and young as determined by

$$
\eta\left(\frac{\alpha_{t}}{\beta_{t}}\right)=u^{\prime}\left(\frac{c_{2 t}}{\beta_{t}}\right)=\frac{1}{1+\rho} u^{\prime}\left(c_{1 t}\right)
$$

while (11) and (16) give the view of the current young on the distribution between old and young.

$$
\eta\left(\frac{\alpha_{t}}{\beta_{t}}\right)=u^{\prime}\left(\frac{c_{2 t}}{\beta_{t}}\right)=(1+\rho) u^{\prime}\left(c_{1 t}\right)
$$

Hence, the generation being old in period $t$ aims at $\frac{c_{2 t}}{\beta_{t}}>c_{1 t}$, while the young holds the opposite view, $\frac{c_{2 t}}{\beta_{t}}<c_{1 t}$. It is implied that the young finds that the old should retire $\left(\frac{\alpha_{t}}{\beta_{t}}\right.$ higher) later than is believed by the old themselves.

Note that this conflict creates an ambiguity wrt to the allocation between young and old for the founding generation. But this ambiguity only applies to the introductory period and does not arise for subsequent periods. In all subsequent periods, the social security scheme is determined by (15),(13) and (14). In the following, the introductory period is not discussed further.

\section{Transfers and retirement age}

It is an implication - cf (15)- that the relation between marginal utility of young and old co-existing in any period of time is

$$
u^{\prime}\left(\frac{c_{2 t+j}}{\beta_{t+j}}\right)=u^{\prime}\left(c_{1 t+j}\right) \frac{1}{(1+\delta)}
$$

For $\delta>0$ this implies that the marginal utility of consumption for old exceeds the marginal utility of consumption for young, i.e. young people have larger consumption than old people.

$$
\frac{c_{2 t+j}}{\beta_{t+j}}<c_{1 t+j}
$$


As long as young individuals save it also holds that

$$
u^{\prime}\left(\frac{c_{2 t}}{\beta_{t}}\right)=u^{\prime}\left(c_{1 t}\right) \frac{1}{(1+\delta)}=\frac{1}{(1+\delta)} \frac{1+r}{1+\theta} u^{\prime}\left(\frac{c_{2 t+j}}{\beta_{t+j}}\right)
$$

i.e. for $\frac{1}{(1+\delta)} \frac{1+r}{1+\theta}<1$ it follows that the marginal utility of consumption for old is increasing from generation to generation, i.e. the consumption flow is falling.

$$
\frac{c_{2 t}}{\beta_{t}}>\frac{c_{2 t+j}}{\beta_{t+j}} \quad \text { for } \quad s_{t}>0
$$

It is shown in the appendix that savings will converge to zero in finite time, cf Hansson and Stuart (1989).

Finally, note that at the margin there is no distortion of the retirement decision, $\operatorname{cf}((13)$, i.e. the retirement age chosen as part of the social security scheme is in accordance with the first best criterion in the absence of a social security system (5). The fact that a mandatory retirement age is stipulated as part of the social security schemes thus ensures that the potential distortion of the retirement decision implied by the implicit tax on postponement of retirement is eliminated.

Note that it is an implication that as long as (19) holds it follows that

$$
\eta\left(\frac{\alpha_{t}}{\beta_{t}}\right) \frac{1}{(1+\delta)} \frac{1+r}{1+\theta}=\eta\left(\frac{\alpha_{t+1}}{\beta_{t+1}}\right)
$$

implying that

$$
\frac{\alpha_{t}}{\beta_{t}}<\frac{\alpha_{t+1}}{\beta_{t+1}} \quad \text { for } s_{t}>0
$$

This implies that younger generations enjoy a relatively longer retirement period than later generations.

The solution implied by (15),(13) and (14) for all $j>0$ has two important properties. The first is that the degree of egoism/altruism measured by $\delta$ determines the relation of e.g. consumption between young and old. Second, the underlying distribution profile is determined by marginal utilities, that is, resources are allocated across generations based on marginal utilities. If old generations have low income, and therefore low consumption, marginal utility of consumption will be high, and this tends to call for redistribution from the young to old. In relation to this, when marginal utility of consumption is high for the old, they tend to retire late and therefore to have a high disutility of work (retirement). By redistributing from the young to the old, it is an implication that this will also result in earlier retirement. Hence, redistribution between generations runs via both consumption and retirement possibilities. These mechanisms are important when there are exogenous changes such as a changes in longevity, cf below. Observe that since longevity is assumed deterministic, it follows that the conditions here determine how the properties of the social security schemes (contributions, benefits and retirement age) are contingent on the longevity of different generations. 


\section{Changes in longevity}

The interesting question here is how the social security scheme is adapted to changes or differences in longevity across different generations. The empirically relevant case is where longevity increases $\left(\beta_{t+1}>\beta_{t}\right)$, and therefore the interpretation of the results refers to this case.

\section{Indexing on longevity is not sustainable}

To set the scene for the discussion of how the properties of the social security system are adjusted to changes in longevity, it is important to note a basic nonneutrality result which follows from simple budgetary reasons. Consider a given allocation where the young consume $c_{1 t+j}$, and the old have a consumption flow $\left(\frac{c_{2 t+j}}{\beta_{t+j}}\right)$ and a relative retirement age $\left(\frac{\alpha_{t+j}}{\beta_{t+j}}\right)$. Then if longevity $\left(\beta_{t+j}\right)$ changes, it is not feasible to have an allocation where i) the young have the same consumption $\left(c_{1 t+j}\right)$, and ii) the old have the same consumption flow $\left(\frac{c_{2 t+j}}{\beta_{t+j}}\right)$ and relative retirement age $\left(\frac{\alpha_{t+j}}{\beta_{t+j}}\right)$. To prove this, note that the aggregate resource constraint reads

$$
1+\alpha_{t+j}=c_{1 t+j}+c_{2 t+j}
$$

or rewritten in terms of consumption flows $\left(\frac{c_{2 t+j}}{\beta_{t+j}}\right)$ and relative retirement $\left(\frac{\alpha}{\beta}\right)$, we have

$$
c_{1 t+j}=1-\beta_{t+j}\left[\frac{c_{2 t+j}}{\beta_{t+j}}-\frac{\alpha_{t+j}}{\beta_{t+j}}\right]
$$

i.e. the consumption of the young is equal to their income (notice that labour supply for the young is normalized to unity as is the real wage rate) minus the longevity of the old times the difference between the consumption and income for the old. It follows that if transfers are made to the old generation $\left(\frac{c_{2 t+j}}{\beta_{t+j}}-\frac{\alpha_{t+j}}{\beta_{t+j}}>0\right)$, then $\left(c_{1 t+j}, \frac{c_{2 t+j}}{\beta_{t+j}}, \frac{\alpha_{t+j}}{\beta_{t+j}}\right)$ cannot all be invariant to longevity $\left(\beta_{t+j}\right)$. The important policy implication of this result is that a simple proportional indexation of total consumption as old $\left(c_{2 t+j}\right)$ and the retirement age $\left(\alpha_{t+j}\right)$ to longevity $\left(\beta_{t+j}\right)$ - implying a constant consumption flow $\frac{c_{2 t+j}}{\beta_{t+j}}$ and relative retirement age $\frac{\alpha_{t+j}}{\beta_{t+j}}$ - is not a sufficient adjustment of the social security scheme to a change in longevity. Clearly, this result does not rely on any specificities of the model, but follows from basic budget mechanisms. Hence, the problem of how to adjust the social security system to increasing longevity cannot simply be solved by indexing key parameters of the social security system to longevity. More complicated distributional issues are involved. It is therefore of interest to explore how the dimensions of the social security system are adapted to changes in longevity. We now turn to the predictions implied by the legislative approach to the political process assumed in this paper.

\section{Political equilibrium}

The basic direction of changes implied by changes in longevity is determined 
by (13) and (14) implying that

$$
\operatorname{sign}\left(\frac{\partial c_{1 t+j}}{\partial \beta_{t+j}}\right)=\operatorname{sign}\left(\frac{\partial \frac{c_{2 t+j}}{\beta_{t+j}}}{\partial \beta_{t+j}}\right)=-\operatorname{sign}\left(\frac{\partial \frac{\alpha_{t+j}}{\beta_{t+j}}}{\partial \beta_{t+j}}\right)
$$

i.e. a change in longevity implies a change in consumption of young and old in the same direction, and the relative retirement age moves in the opposite direction. This accords with the remarks made above on the role of marginal utilities in determining the extent of redistribution across generations. If consumption opportunities fall (increase), there is a case of sharing the fall across both young and old generations to avoid differences (beyond those caused by the degree of egoism/altruism) in marginal utilities. Likewise, if consumption falls for old and the marginal utility of consumption thereby increases, there is a case for increasing the relative retirement age, and vice versa.

More specifically, it can be shown ${ }^{12}$ that

$$
\frac{\partial c_{1 t+j}}{\partial \beta_{t+j}}<0, \frac{\partial \frac{c_{2 t+j}}{\beta_{t+j}}}{\partial \beta_{t+j}}<0, \frac{\partial \frac{\alpha_{t+j}}{\beta_{t+j}}}{\partial \beta_{t+j}}>0
$$

Hence, an increase in longevity causes a decrease in consumption for both young and old, and the old retire later. The current generation - the young - thus accepts lower consumption (higher contributions) when the old experience an increase in longevity, i.e. they accept sharing some of the financial burden ${ }^{13}$. The reason is straightforward; an increase in longevity will - other things being equal - lower consumption as old and therefore increase the marginal utility of consumption. Therefore, there is always an incentive to distribute in favour of generations with longer longevity. Considering the retirement age, it is an implication that it increases both absolute and relative to longevity ( $\frac{\alpha}{\beta}$ increases), and this is an obvious implication of the fact that marginal utility of consumption increases. Note that although the relative retirement age increases, this is not necessarily implying that the absolute retirement period falls, since we have

$$
\frac{\partial\left(\beta_{t+j}-\alpha_{t+j}\right)}{\partial \beta_{t+j}}=1-\frac{\alpha_{t+j}}{\beta_{t+j}}-\frac{\partial \frac{\alpha_{t+j}}{\beta_{t+j}}}{\partial \beta_{t+j}} \lesseqgtr 0
$$

Note that the adjustment of consumption across young and old is not in general proportional. This is seen by using (17) implying that

$$
\Xi_{\frac{c_{2 t+j}}{\beta_{t+j}}, \beta_{t+j}}=\frac{\Xi_{u^{\prime}, c_{1 t+j}}}{\Xi_{u^{\prime}, \frac{c_{2 t+j}}{\beta_{t+j}}}} \Xi_{c_{1 t+j}, \beta_{t+j}}
$$

\footnotetext{
${ }^{12}$ First, note that the resource constraint implies$$
\frac{\partial c_{1 t}}{\partial \beta_{t}}=-\left[\frac{c_{2 t}}{\beta_{t}}-\frac{\alpha_{t}}{\beta_{t}}\right]-\beta_{t}\left[\frac{\partial \frac{c_{2 t}}{\beta_{t}}}{\partial \beta_{t}}-\frac{\partial \frac{\alpha_{t}}{\beta_{t}}}{\partial \beta_{t}}\right]
$$

The proof runs by contradiction. Assume that $\frac{\partial \frac{\alpha_{t}}{\beta_{t}}}{\partial \beta_{t}}<0$, and hence $\frac{\partial \frac{c_{2 t}}{\beta_{t}}}{\partial \beta_{t}}>0, \frac{\partial c_{1 t}}{\partial \beta_{t}}>0$ from (20). However, the relation above implies $\frac{\partial c_{1 t}}{\partial \beta_{t}}<0$, and hence a contradiction.

${ }^{13}$ Note that this also holds for the founding generation.
} 
where $\Xi_{x, y}$ denotes the elasticity of $x$ wrt. $y$. Hence, the consumption of current young may adjust by more or less than for the old when longevity changes. This depends on the relative risk aversion, i.e. the sensitivity of marginal utilities to changes in consumption. Only in the limiting case of constant relative risk aversion $\left(\Xi_{u^{\prime}, c_{1}}=\Xi_{u^{\prime}, \frac{c_{2 t}}{\beta_{t}}}=\right.$ constant) is the consumption adjustment for young and old proportional.

Similarly, it follows that the adjustment of the relative retirement age may differ from that of the adjustment in consumption since

$$
\Xi_{\frac{\alpha_{t+j}}{\beta_{t+j}}, \beta_{t+j}}=\frac{\Xi_{u^{\prime}, \frac{c_{2 t+j}}{\beta_{t+j}}}}{\Xi_{\eta, \frac{\alpha_{t+j}}{\beta_{t+j}}}} \Xi_{\frac{c_{2 t+j}}{\beta_{t+j}}, \beta_{t+j}}
$$

An interesting question is how the benefit ratio $(\tau)$ is adjusted. Generations are sharing a consumption adjustment, but the old generation is retiring later. We have from the budget constraint that the benefit ratio is given as

$$
\tau_{t+j}=\frac{\frac{c_{2 t+j}}{\beta_{t+j}}-\frac{\alpha_{t+j}}{\beta_{t+j}}}{1-\frac{\alpha_{t+j}}{\beta_{t+j}}}
$$

and it follows that the benefit ratio is decreasing in longevity ${ }^{14}$, i.e.

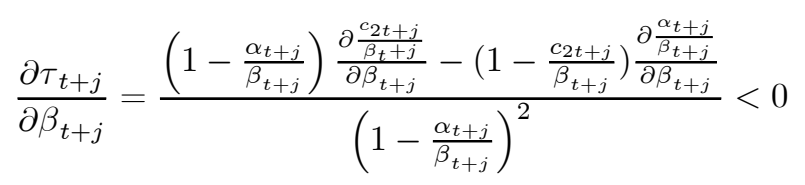

The benefit ratio is thus lower the larger the longevity. However, note that the current young share the consequences of the increase in longevity in the form of low consumption, and therefore the gross transfer from young to old is increasing in longevity, i.e.

$$
\frac{\partial T_{t}}{\partial \beta_{t}}=-\frac{\partial c_{1 t+j}}{\partial \beta_{t+j}}>0
$$

Hence, although the benefit ratio is decreased and the retirement age increased, the net effect is that young transfer more to old with longer longevity. In sum, we find that the social security scheme is adjusted in all three dimensions - contribution rate for the young increases, the benefit ratio for the old decreases, and the retirement age increases (more than proportionally to longevity).

\section{Concluding remarks}

The adaptation of the social security system to changes in longevity has been considered in a basic OLG framework. A key finding is that a proportional

\footnotetext{
${ }^{14}$ Note that $\frac{c_{2 t+j}}{\beta_{t+j}}<1$. This follows by observing that $\frac{c_{2 t+j}}{\beta_{t+j}}>1$ leads to a contradiction since $c_{1 t+j}>\frac{c_{2 t+j}}{\beta_{t+j}}$, cf (18), which will violate the aggregate resource constraint.
} 
indexation of benefits and retirement ages to longevity is not ensuring viability of the social security system, and therefore more difficult political choices are involved. These issues have been addressed by following the legislative approach which has the attraction that it allows for an analysis of welfare improving social security schemes which can actually be implemented and supported by a fairly simple political decision structure. Once in place, there is no incentive for future generations to amend the social security scheme, but its properties (contributions, benefits and retirement age) are contingent on longevity.

The main interest has been to explore how the properties of social security depend on longevity. The concern of current generations as regards past and future generations which, in the first place, can rationalize why a social security scheme can be implemented also implies that all living generations share the adjustment burden arising due to increasing longevity. Hence, even though current old would benefit directly from longer longevity, they also receive a larger transfer from the young, i.e. the current young accept lower consumption when the old have longer longevity. The basic reason is that with larger longevity the marginal utility of consumption for the old increases, and this tends to increase the transfer to the old. However, the benefit ratio also decreases, and the retirement age increases. The latter reflects that the old also participate in "financing" longer longevity by relatively later retirement.

\section{Appendix}

From (19) we have when consumption is positive that

$$
u^{\prime}\left(\frac{c_{2 t}}{\beta_{t}}\right)=\frac{1}{(1+\delta)} \frac{1+r}{1+\theta} u^{\prime}\left(\frac{c_{2 t+1}}{\beta_{t+1}}\right)
$$

where $\frac{1}{(1+\delta)} \frac{1+r}{1+\theta}<1$. Using this and (4) we also have

$$
u^{\prime}\left(c_{1 t}\right)=\frac{1}{(1+\delta)} \frac{1+r}{1+\theta} u^{\prime}\left(c_{1 t+1}\right)
$$

hence, $u^{\prime}\left(c_{t+j}\right)$ and $u^{\prime}\left(\frac{c_{2 t+j}}{\beta_{t+j}}\right)$ must go to $\infty$ for $j$ going to $\infty$. This implies that $c_{t+j}$ and $\frac{c_{2 t+j}}{\beta_{t+j}}$ go to zero.

The budget constraint implies

$$
s_{t+j}-(1+r) s_{t+j-1}=1-c_{1 t+j}+c_{2 t+j}
$$

hence $s_{t+j}$ must go to $\infty$ for $j$ going to $\infty$. This contradicts $s_{t+j} \leq 1$. Hence, a contradiction and $s_{t+j}=0$ for some $j>0$.

\section{References}

Andersen, T.M. and R.R. Dogonowski, 2002, Social Insurance and the Public Budget, Economica, 69, 415-432.

Andersen, T. M., 2005, Social Security and Longevity, CESifo Working Paper 1577. 
Azariadis, C., and V. Galasso, 2002, Fiscal Constitutions, Journal of Economic Theory, 103, 255-281.

Auerbach, A. and K. Hassett, 2002a, Fiscal policy and uncertainty, International Finance, 5(2), 229-242.

Auerbach, A. and K. Hassett, 2002b, Optimal long-run fiscal policy: Constraints, Preferences and the Resolution of Uncertainty, NBER Working Paper 7036 .

Ball, L: and N.G. Romer, 2001, Intergenerational Risk Sharing in the Spirit of Arrow, Debreu, and Rawls, with Applications to Social Security Design, NBER Working Paper 8270.

Bohn, H., 2001, Social Security and Demographic Uncertainty: The Risk Sharing Properties of Alternative Policies, in Risk Aspects of Investment Based Social Security Reform, ed. by J.Campbell and M. Feldstein, University of Chicago Press, Chicago.

Börsch-Supan, A., 2004, From Traditional DB to Notional DC Systems: The Pension Reform Process in Sweden, Italy and Germany, Journal of the European Economic Association, Papers and Proceedings, 3, 458-465.

Caballero, R., 1991, Earnings Uncertainty and Aggregate Wealth Accumulation, American Economic Review, 81(4), 859-871.

Conde-Ruiz, J.I., and V. Galasso, 2003, Early retirement, Review of Economic Dynamics, 6, 12-36.

Conde-Ruiz, J.I., and V. Galasso, 2004, The macroeconomics of early retirement, Journal of Public Economics, 88, 1849-1869.

Cremer, H., J.-M. Lozachmeur, and P. Pestieau, 2006, Social Security and Retirement Decision: A Positive and Normative Approach, CEPR Discussion Paper 5542.

Diamond., P., 2004, Social security, American Economic Review, 94, 1-24.

European Commission, 2006. The impact of ageing on public expenditures - projections for the EU 25 member states on pensions, health care, long term care, education and unemployment transfers, 2004-2050, Special report 1/2006

Galasso, V., and P.Profeta, 2002, The political economy of social security: a survey, European Journal of Political Economy, 18, 1-29.

Gordon, R. and H. Varian, 1988, Intergenerational Risk Sharing, Journal of Public Economics, 37, 185-202.

Hansson, I., and C. Stuart, 1989, Social Security as Trade Among Living Generations, American Economic Review, 79, 1182-1195.

IMF, 2004, World Economic Outlook, September 2004

Lippmann,S. and J. McCall, 1981, The Economics of Uncertainty: Selected Topics and Probabilistic Methods, in Handbook of Mathematical Economics, ed. by K.J.Arrow and M.D. Intrilligator, ch. 6, North-Holland, Amsterdam.

Mulligan, C.B. and X. Sala-I-Martin, 2003, Social Secutiry, Retirement, and the Single-Mindedness of the Electorate, NBER Working Paper 9691.

Mulligan, C.B. and X. Sala-I-Martin, 2004a, Internationally Common Features of Public Old-Age Pensions, and Their Implications for Models of the Public Sector, Advances in Economic and Analysis, B.E: Journals in Economic Analysis and Policy, 4, 
Mulligan, C.B. and X. Sala-I-Martin, 2004a, Political and Economic Forces Sustaining Social Security, Advances in Economic and Analysis, B.E: Journals in Economic Analysis and Policy, 5,

Padilla, E., 2002, Intergenerational equity and sustainability, Ecological Economics, 41, 69-83.

Talmain, G., 1998, An analytical approximate solution to the problem of precautionary savings, Journal of Economic Dynamics and Control, 23, 113124.

United Nations, 2004, World Population in 2300, UN, New York.

Velfærdskommissionen, 2005, Fremtidens velfærd - sådan gør andre lande, analyserapport.

Werding, M., 2004, Assessing Old-age Pension Benefits: The Rules Applied in Different Countries, CESifo Bulletin, 2(2), 55-63.

Woodward, R.T., 2000, Sustainability as Intergenerational Fairness: Efficiency, Uncertainty, and Numerical Methods, American Journal of Agricultural Economics, 82, 581-593.

Yaari, M., 1965, Uncertain Lifetime, Insurance and the Theory of the Consumer, Review of Economic Studies, 32, 137-50. 


\section{CESifo Working Paper Series}

(for full list see www.cesifo-group.de)

1724 Axel Dreher and Jan-Egbert Sturm, Do IMF and World Bank Influence Voting in the UN General Assembly?, May 2006

1725 Swapan K. Bhattacharya and Biswa N. Bhattacharyay, Prospects of Regional Cooperation in Trade, Investment and Finance in Asia: An Empirical Analysis on BIMSTEC Countries and Japan, May 2006

1726 Philippe Choné and Laurent Linnemer, Assessing Horizontal Mergers under Uncertain Efficiency Gains, May 2006

1727 Daniel Houser and Thomas Stratmann, Selling Favors in the Lab: Experiments on Campaign Finance Reform, May 2006

1728 E. Maarten Bosker, Steven Brakman, Harry Garretsen and Marc Schramm, A Century of Shocks: The Evolution of the German City Size Distribution 1925 - 1999, May 2006

1729 Clive Bell and Hans Gersbach, Growth and Enduring Epidemic Diseases, May 2006

1730 W. Bentley MacLeod, Reputations, Relationships and the Enforcement of Incomplete Contracts, May 2006

1731 Jan K. Brueckner and Ricardo Flores-Fillol, Airline Schedule Competition: ProductQuality Choice in a Duopoly Model, May 2006

1732 Kerstin Bernoth and Guntram B. Wolff, Fool the Markets? Creative Accounting, Fiscal Transparency and Sovereign Risk Premia, May 2006

1733 Emmanuelle Auriol and Pierre M. Picard, Government Outsourcing: Public Contracting with Private Monopoly, May 2006

1734 Guglielmo Maria Caporale and Luis A. Gil-Alana, Modelling Structural Breaks in the US, UK and Japanese Unemployment Rates, May 2006

1735 Emily J. Blanchard, Reevaluating the Role of Trade Agreements: Does Investment Globalization Make the WTO Obsolete?, May 2006

1736 Per Engström and Bertil Holmlund, Tax Evasion and Self-Employment in a High-Tax Country: Evidence from Sweden, May 2006

1737 Erkki Koskela and Mikko Puhakka, Cycles and Indeterminacy in Overlapping Generations Economies with Stone-Geary Preferences, May 2006

1738 Saku Aura and Thomas Davidoff, Supply Constraints and Housing Prices, May 2006 
1739 Balázs Égert and Ronald MacDonald, Monetary Transmission Mechanism in Transition Economies: Surveying the Surveyable, June 2006

1740 Ben J. Heijdra and Ward E. Romp, Ageing and Growth in the Small Open Economy, June 2006

1741 Robert Fenge and Volker Meier, Subsidies for Wages and Infrastructure: How to Restrain Undesired Immigration, June 2006

1742 Robert S. Chirinko and Debdulal Mallick, The Elasticity of Derived Demand, Factor Substitution and Product Demand: Corrections to Hicks' Formula and Marshall's Four Rules, June 2006

1743 Harry P. Bowen, Haris Munandar and Jean-Marie Viaene, Evidence and Implications of Zipf's Law for Integrated Economies, June 2006

1744 Markku Lanne and Helmut Luetkepohl, Identifying Monetary Policy Shocks via Changes in Volatility, June 2006

1745 Timo Trimborn, Karl-Josef Koch and Thomas M. Steger, Multi-Dimensional Transitional Dynamics: A Simple Numberical Procedure, June 2006

1746 Vivek H. Dehejia and Yiagadeesen Samy, Labor Standards and Economic Integration in the European Union: An Empirical Analysis, June 2006

1747 Carlo Altavilla and Paul De Grauwe, Forecasting and Combining Competing Models of Exchange Rate Determination, June 2006

1748 Olaf Posch and Klaus Waelde, Natural Volatility, Welfare and Taxation, June 2006

1749 Christian Holzner, Volker Meier and Martin Werding, Workfare, Monitoring, and Efficiency Wages, June 2006

1750 Steven Brakman, Harry Garretsen and Charles van Marrewijk, Agglomeration and Aid, June 2006

1751 Robert Fenge and Jakob von Weizsäcker, Mixing Bismarck and Child Pension Systems: An Optimum Taxation Approach, June 2006

1752 Helge Berger and Michael Neugart, Labor Courts, Nomination Bias, and Unemployment in Germany, June 2006

1753 Chris van Klaveren, Bernard van Praag and Henriette Maassen van den Brink, A Collective Household Model of Time Allocation - a Comparison of Native Dutch and Immigrant Households in the Netherlands, June 2006

1754 Marko Koethenbuerger, Ex-Post Redistribution in a Federation: Implications for Corrective Policy, July 2006 
1755 Axel Dreher, Jan-Egbert Sturm and Heinrich Ursprung, The Impact of Globalization on the Composition of Government Expenditures: Evidence from Panel Data, July 2006

1756 Richard Schmidtke, Private Provision of a Complementary Public Good, July 2006

1757 J. Atsu Amegashie, Intentions and Social Interactions, July 2006

1758 Alessandro Balestrino, Tax Avoidance, Endogenous Social Norms, and the Comparison Income Effect, July 2006

1759 Øystein Thøgersen, Intergenerational Risk Sharing by Means of Pay-as-you-go Programs - an Investigation of Alternative Mechanisms, July 2006

1760 Pascalis Raimondos-Møller and Alan D. Woodland, Steepest Ascent Tariff Reforms, July 2006

1761 Ronald MacDonald and Cezary Wojcik, Catching-up, Inflation Differentials and Credit Booms in a Heterogeneous Monetary Union: Some Implications for EMU and new EU Member States, July 2006

1762 Robert Dur, Status-Seeking in Criminal Subcultures and the Double Dividend of ZeroTolerance, July 2006

1763 Christa Hainz, Business Groups in Emerging Markets - Financial Control and Sequential Investment, July 2006

1764 Didier Laussel and Raymond Riezman, Fixed Transport Costs and International Trade, July 2006

1765 Rafael Lalive, How do Extended Benefits Affect Unemployment Duration? A Regression Discontinuity Approach, July 2006

1766 Eric Hillebrand, Gunther Schnabl and Yasemin Ulu, Japanese Foreign Exchange Intervention and the Yen/Dollar Exchange Rate: A Simultaneous Equations Approach Using Realized Volatility, July 2006

1767 Carsten Hefeker, EMU Enlargement, Policy Uncertainty and Economic Reforms, July 2006

1768 Giovanni Facchini and Anna Maria Mayda, Individual Attitudes towards Immigrants: Welfare-State Determinants across Countries, July 2006

1769 Maarten Bosker and Harry Garretsen, Geography Rules Too! Economic Development and the Geography of Institutions, July 2006

1770 M. Hashem Pesaran and Allan Timmermann, Testing Dependence among Serially Correlated Multi-category Variables, July 2006

1771 Juergen von Hagen and Haiping Zhang, Financial Liberalization in a Small Open Economy, August 2006 
1772 Alessandro Cigno, Is there a Social Security Tax Wedge?, August 2006

1773 Peter Egger, Simon Loretz, Michael Pfaffermayr and Hannes Winner, Corporate Taxation and Multinational Activity, August 2006

1774 Jeremy S.S. Edwards, Wolfgang Eggert and Alfons J. Weichenrieder, The Measurement of Firm Ownership and its Effect on Managerial Pay, August 2006

1775 Scott Alan Carson and Thomas N. Maloney, Living Standards in Black and White: Evidence from the Heights of Ohio Prison Inmates, 1829 - 1913, August 2006

1776 Richard Schmidtke, Two-Sided Markets with Pecuniary and Participation Externalities, August 2006

1777 Ben J. Heijdra and Jenny E. Ligthart, The Transitional Dynamics of Fiscal Policy in Small Open Economies, August 2006

1778 Jay Pil Choi, How Reasonable is the 'Reasonable' Royalty Rate? Damage Rules and Probabilistic Intellectual Property Rights, August 2006

1779 Ludger Woessmann, Efficiency and Equity of European Education and Training Policies, August 2006

1780 Gregory Ponthiere, Growth, Longevity and Public Policy, August 2006

1781 Laszlo Goerke, Corporate and Personal Income Tax Declarations, August 2006

1782 Florian Englmaier, Pablo Guillén, Loreto Llorente, Sander Onderstal and Rupert Sausgruber, The Chopstick Auction: A Study of the Exposure Problem in Multi-Unit Auctions, August 2006

1783 Adam S. Posen and Daniel Popov Gould, Has EMU had any Impact on the Degree of Wage Restraint?, August 2006

1784 Paolo M. Panteghini, A Simple Explanation for the Unfavorable Tax Treatment of Investment Costs, August 2006

1785 Alan J. Auerbach, Why have Corporate Tax Revenues Declined? Another Look, August 2006

1786 Hideshi Itoh and Hodaka Morita, Formal Contracts, Relational Contracts, and the Holdup Problem, August 2006

1787 Rafael Lalive and Alejandra Cattaneo, Social Interactions and Schooling Decisions, August 2006

1788 George Kapetanios, M. Hashem Pesaran and Takashi Yamagata, Panels with Nonstationary Multifactor Error Structures, August 2006

1789 Torben M. Andersen, Increasing Longevity and Social Security Reforms, August 2006 